\title{
PENANAMAN NILAI-NILAI KARAKTER DALAM PENDIDIKAN AGAMA ISLAM MELALUI METODE BERCERITA DI SD N 07 SUMANIK KECAMATAN SALIMPAUNG KABUPATEN TANAH DATAR
}

Mhd. Aulia Fiman Puldri

e-mail: puld riauliafiman@ya hoo.co.id

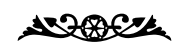

\begin{abstract}
The problem in this research is the cultivation of character values by PAI teacher through storytelling and character values any implanted through storytelling. The purpose of this study is to describe the process of cultivation of character values in Islamic education through storytelling. The method used a qualitative research method with type research field research is descriptive qualitative. The data source is the PAI teacher. The research location is in SD N 07 Sumanik Salimpaung District of Tanah Datar. Namely data collection techniques of observation, interviews and documentation. Data processing techniques by collecting data, once collected then checked and diklasifiasikan, so make easy in data processing. Analysis of the data used is, selecting the data, classifying the data, content analysis, and conclusion. Technique authenticity of data is triangulation is using a variety of sources, such as interviews with respondents and researcher observation and documentation. The results showed that the learning process in primary PAI SD N 07 Sumanik Salimpaung District of Tanah Datar, through storytelling in the cultivation of character values categorized as good, with storytelling techniques without the help of using media images. However, there are some components of storytelling process that has not been done as it should be, as in the stage of arranging the seating of students, at this stage of asking the students to retell the stories that have been submitted. From the stories presented by the teacher in the classroom learning process PAI their character values are imparted to students, among others: (1) The value of character religious, (2) honest, (3) tolerance, (4) hard work, (5) curiosity, (6) the national spirit, (7) recognize excellence, (8) friends / communicative, (9) love peace, (10) social care, and (11) of responsibility. While the character values (1) discipline, (2) independent, (3) democratic, (4) likes to read, (5) love of the homeland, (6) creative, and (7) to care for the environment has not seen imparted to students through methods of the story told.
\end{abstract}

Keywords: Planting, values character, Storytelling Method, Islamic Education, Character Education.

\section{PENDAHULUAN}

Pendidikan telah menjadi perhatian seluruh lapisan masyarakat dari sejak dahulu kala. Bangsa Hindu misalnya mengarahkan pendidikannya pada pembiasaan (melatih) anak didik agar bersikap sabar dan menerima kenyataan yang ada, serta mampu menahan hawa nafsu. Sementara itu, bangsa Sparta yang lebih mengutamakan pendidikan kepada pembentukan sifat-sifat keberanian 
dan kesabaran serta sikap menghormati para pemimpin dan patriotis (mencintai tanah air) serta taat kepada pemerintahnya, mengarahkan pendidikannya kepada menghasilkan manusia yang gagah berani dan rela berkorban. Sementara itu, bangsa Athena (Yunani) mengarahkan pendidikan pada pembentukan pribadi yang berkeseimbangan dalam aspek-aspek jasmaniah dan kecerdasan, moral, serta keindahan budi (Abudin, 2014:349).

Melalui sistem pendidikan yang dilaksanakan di Indonesia, seharusnya Indonesia menjadi negara yang berkembang dengan baik. Dengan rumusan batang tubuh UUD 1945 mengamanatkan bahwa pemerintah mengusahakan dan menyelenggarakan satu sistem pendidikan nasional untuk meningkatkan keimanan dan ketaqwaan kepada Tuhan Yang Maha Esa serta akhlak mulia dalam rangka mencerdaskan kehidupan bangsa.(Direktorat Pembinaan Anak Usia Dini, 2012:2). Cita-cita bangsa Indonesia adalah menjadi Negara besar, kuat, disegani dan dihormati keberadaannya di tengahtengah bangsa-bangsa di dunia.(Prayitno dan Balferik Manullang, 2010: i). Pada dekadedekade awal kemerdekaan serta pembangunan bangsa dan negara Indonesia dikenal dan dikumandangkan dua "slogan" tetapi satu yaitu nation and character building yang maknanya pembangunan bangsa dan pembangunan watak (karakter) bangsa (2010: 12).

Inti pendidikan adalah pembelajaran. Pembelajaran dapat berlangsung secara alamiah melalui pemaknaan individu terhadap pengalaman-pengalamannya dalam menjalani kehidupan. Pembelajaran sebagai rekayasa sosial untuk pembudayaan manusia dilakukan melalui pendidikan informal, formal dan nonformal.(Prayitno dan Balferik Manullang, 2010: 15). Dalam era globalisasi saat ini dunia terasa sangat kecil, dengan perkembangan teknologi yang begitu cepat membuat manusia dapat begitu mudah memperoleh informasi. Saat ini Indonesia mengalami krisis multi dimensi, diantaranya permasalahan-permasalahan yang timbul di negara indonesia ini adalah penyimpangan moral seperti: seks bebas, tawuran pelajar, kebut-kebutan di jalan para pelajar, pengguna narkoba, minuman keras, perjudian, kasus korupsi, perampokan, bom bunuh diri teroris, dan baru-baru ini yang paling mencengangkan kasus video porno pelakunya adalah seorang artis idola dimasyarakat, serta seorang anggota Dewan Perwakilan Rakyat (DPR) nonton video porno saat sidang di gedung DPR.

Dengan adanya beragam fenomena yang semakin krisis tentang karakter individu dan kurang pekanya orang tua dalam mendidik anak, maka penting untuk diadakan sebuah upaya untuk dapat menumbuhkan karakter pada anak, khususnya karakter yang Islami, supaya anak dapat tumbuh dan berkembang dengan karakter yang Islami. Ketika seorang anak telah diupayakan pertumbuhan karakternya supaya dapat memiliki karakter yang Islami, maka diharapkan individu akan dapat menjadi pribadi yang Islami 
pula ketika memasuki masa remaja, dewasa, bahkan setelah tua.Pendidikan karakter menjadi tema sentral sejak beberapa tahun terakhir dalam perkembangan pendidikan di Tanah Air. Dunia pendidikan diharapkan sebagai motor penggerak untuk memfasilitasi pembangunan karakter, sehingga anggota masyarakat mempunyai kesadaran kehidupan berbangsa dan bernegara yang harmonis dan demokratis dengan tetap memperhatikan norma-norma di masyarakat yang telah menjadi kesepakatan bersama (Vivit Risnawati: Jurnal Pesona PAUD Vol.1 No.1) Faktor lain yang menyebabkan pentingnya pendidikan karakter adalah, karena sistem pendidikan yang lebih mengutamakan atau menekankan pada aspek intelektual atau ranah kognitif.Penguatan pendidikan moral (moral education) atau pendidikan karakter (character education) dalam konteks sekarang sangat relevan untuk mengatasi krisis moral yang sedang melanda di negara kita. Krisis tersebut antara lain berupa meningkatnya pergaulan bebas, maraknya angka kekerasan anak-anak dan remaja, kejahatan terhadap teman, pencurian remaja, kebiasaan menyontek, penyalahgunaan obat-obatan, pornografi, dan perusakan milik orang lain sudah menjadi masalah sosial yang hingga saat ini belum dapat diatasi secara tuntas, oleh karena itu betapa pentingnya pendidikan karakter. Imam al-Ghazaly berpendapat bahwa pendidikan agama harus mulai diajarkan kepada anak sedini mungkin, pertama kali dengan mendidik hati mereka dengan ilmu Pengetahuan dan mendidik jiwanya dengan ibadah. (Fahtiyah Hasan Sulaiman, 61).Megawangi menyebutkan, pendidikan karakter yang baik adalah pendidikan yang dimulai sedini mungkin dalam keluarga. Menurut Azyumardi Azra proses pendidikan karakter di sekolah yaitu Menerapkan pendekatan modeling, yakni mensosialisasikan dan membiasakan lingkungan sekolah untuk menghidupkan nilai-nilai akhlak dan moral yang benar melalui model/teladan, menjelaskan atau mengklarifikasikan kepada siswa secara terus menerus tentang berbagai nilai yang baik dan buruk, dan menerapkan pendidikan berdasarkan karakter (character based education). Dalam mendidik siswa, guru dituntut menerapkan pendidikan yang berdasarkan pada nilai - nilai karakter.(Arif Rohman, 2009: 20)

Kegiatan belajar bagi anak usia sekolah dasar mempunyai arti dan tujuan tersendiri. Seorang guru sekolah dasar sewajarnya memahami bahwa komponen anak merupakan komponen terpenting dalam proses pengajaran. Proses pengajaran itu harus diciptakan atas dasar pemahaman siapa dan bagaimana anak tumbuh dan berkembang. Kegiatan belajar mengajar yang secara praktis dikembangkan guru disekolah dasar dituntut untuk berorientasi pada perkembangan anak secara tepat.

Tujuan pendidikan di sekolah dasar sendiri dapat diuraikan meliputi beberapa hal yaitu, (1). Beriman dan bertaqwa terhadap TuhanNya, (2). Mengarahkan 
dan membimbing siswa ke arah situasi yang berpotensi positif, berjiwa besar, kritis,cerdas dan berakhlak mulia, (3). Memiliki rasa cinta tanah air, bangga dan mampu mengisi hal yang bertujuan membangun diri sendiri bangsa dan negara, (4). Membawa siswa sekolah dasar mampu berprestasi ke jenjang selanjutnya.

Inti pokok pendidikan sekolah dasar, berupaya menanamkan keimanan terhadap Tuhan sesuai dengan agama masing-masing yang dianutnya. Dengan harapan tentunya siswa dapat menanamkan sikap yang berakhlak, sopan dan santun antar sesama umat manusia tanpa membedakan ras, suku, dan agama. Sehingga pada akhirnya siswa dapat menjadi individu yang bertanggung jawab, cakap, berdedikasi tinggi terhadap bangsa dan negaranya. Pengertian pendidikan di sekolah dasar benar-benar mendidik dan menumbuhkembangkan ilmu pengetahuan pada siswa di sekolah dasar untuk memiliki sikap kebersamaan dalam upaya mencetak generasi muda yang bertanggung jawab. (http://disdik.bekasikab.go.id).

Pendidikan Agama Islam sangat berpotensi besar untuk membentuk karakter peserta didik, jika Pendidikan Agama Islam tersebut dijadikan dasar bagi seluruh penyelenggara pendidikan. (Abudin Nata, 2014: 364). Salah satu dari metode pendidikan Islam adalah metode pelajaran berhikmah dan kisah (cerita). Metode ini digunakan sejak diturunkannya wahyu sampai sekarang. Bahkan dalam perkembangan metode ini telah menjadi bagian dari pelajaran bahasa dan ditentukan jam khusus untuk itu, hal ini telah ada dalam sistem pendidikan modern terbukti dengan dimasukkannya cerita dalam kurikulum sekolah.(Abdul Aziz Abdul Majid: 2002" VIII). Sebahagian ulama terdahulu juga berpendapat bahwa cerita merupakan salah satu senjata Allah yang dapat meneguhkan hati para wali-Nya, Imam Abu Hanifah juga berkata, "Kisah-kisah tentang para ulama dan perbuatan baik mereka lebih saya sukai dari pada ilmu fikih sebab kisah merupakan adab suatu kaum".(Syaihk Muhammad Såid Mursi: 2001: 117).

Kisah ataupun cerita memang sangat menarik untuk dikaji, karena cerita itu sendiri mampu mengambil hati para pendengarnya/pembacanya baik itu orang dewasa apalagi anak-anak. Dari hal tersebut di atas saat ini banyak dijumpai buku-buku cerita yang diterbitkan dan diperuntukkan bagi anak-anak maupun dewasa. Berbagai macam cerita tersebut tidak semuanya layak dikunsumsi (dibaca) oleh anak-anak. Para orangtua dan pendidik haruslah mampu untuk menyeleksi, menyaring atau memfilter buku-buku cerita yang pantas diberikan kepada anak-anaknya.

Aktivitas bercerita dapat membantu murid untuk melatih imajinasi dan keterampilan berbahasa melalui aktivitas menceritakan kembali. Murid juga mengembangkan episode-episode atau versiversi baru dengan gambaran dan imajinasi 
yang berdasarkan cerita aslinya.(Rahmandto, 1988: 115-116). Penerapan metode bercerita sebagai salah satu aspek untuk penanaman nilai-nilai moral, hendaknya dapat menghadirkan pengalaman baru yang memperkaya jiwa anak-anak kita. Jika kita pernah mendengarkan kata mutiara, experience is the best teacher, kata itulah ungkapan yang paling tepat diutarakan, bahwa pengalaman adalah guru terbaik dalam kehidupan.

Dalam proses pendidikan, SD N 07 Sumanik Nagari Sumanik Kecamatan Salimpaung Kabupaten Tanah Datar sebagai institusi pendidikan, di dalamnya tentu memuat berbagai macam kegiatan dan pelajaran baik yang dilaksanakan di dalam kelas maupun di luar kelas, dan dengan berbagai macam metode, seperti metode bercerita, media bergambar, menonton cuplikan clip (video) dan lain-lain. Setelah melakukan wawancara dengan guru Pendidikan Agama Islam yang mengajar di Sekolah Dasar Negeri 07 Sumanik Nagari Sumanik, maka dalam penelitian ini metode bercerita menjadi fokus bagi peneliti untuk dijadikan obyek penelitian, melihat penanaman karakter anak didik melalui metode bercerita.

Sekolah Dasar Negeri 07 Sumanik Nagari Sumanik melaksanakan beberapa kegiatan dan metode untuk menanamkan nilai-nilai karakter seperti berdo'a sebelum belajar, bersalaman dengan guru datang ke sekolah, mengucapkan salam ketika masuk kelas. Melalui pembiasaan juga ada dilakukan atau diterapkan di SD N 07 Sumanik Nagari Sumanik, tetapi disesuaikan dengan tingkatan kelas, seperti shalat dzhuhur berjamaah, mengucapkan salam/ menyapa kepada guru ketika bertemu. Dalam mata pelajaran pendidikan agama Islam, Metode bercerita atau materi yang akan disampaikan dengan/melalui cerita di laksanakan sesuai dengan materi yang akan di ajarkan, terkadang metode bercerita yang dilaksanakan oleh guru mata pelajaran menggunakan media gambar, akan lebih menarik bagi anak didik untuk mendengarkan serta menyimak cerita yang disampaikan oleh gurunya.(Observasi awal dan wawancara guru PAI SD N 07 Sumanik). SD N 07 Sumanik banyak meraih prestasi dalam berbagai cabang baik itu olah raga, keagamaan, maupun sains. SD N 07 Sumanik juga pernah meraih hasil UN Agama terbaik di Kecamatan Salimpaung sebagai peringkat satu dalam hasil UN Agama. SD N 07 Sumanik juga mendapatkan akreditasi A.

Berangkat dari semua itu peneliti tertarik untuk meneliti tentang bagaimana penanaman nilai-nilai karakter pada anak didik melalui metode bercerita yang mulai diterapkan di SD N 07 Sumanik Nagari Sumanik Kecamatan Salimpaung Kabupaten Tanah Datar.

\section{KAJIAN TEORI}

Secara etimologis, kata karakter berasal dari baha Yunani yaitu greek, yaitu

Penanaman Nilai-Nilai Karakter dalam Pendidikan Agama Islam... $\quad$ 65 
charassem yang berarti to engrave. (Kevin Ryan \& Karen E: 1999: 5) Kata to engrave bisa diterjemahkan mengukir, melukis, memahatkan atau menggoreskan. (Echols John M dan Hasan Shadily, 1987: 214). Dalam Kamus Bahasa Indonesia kata karakter diartikan dengan tabiat, sifat-sifat kejiwaan, akhlak atau budi pekerti yang membedakan seseorang dengan yang lain. Oleh sebab itu, seseorang yang berperilaku tidak jujur, kejam, atau rakus dikatakan sebagai orang yang berkarakter jelek, sementara seorang yang berperilaku jujur, suka menolong dikatakan sebagai orang yang berkarakter mulia. Jadi istilah karakter erat kaitanya dengan kepribadian(personality) seseorang. Seseorang bisa disebut orang yang berkarakter (a person of character) apabila perilakunya sesuai dengan kaidah moral. (Zubaedi, 2012: 12).

Sedangkan di dalam terminologi Islam, karakter disamakan dengan khuluq (bentuk tunggal dari akblaq) akhlak yaitu kondisi batiniyah (dalam) dan lahiriah (luar) manusia. Kata akhlak berasal dari kata khalaqa (خَ)َ) yang berarti perangai, tabiat, adat istiadat. Menurut pendekatan etimologi kata akhlaq berasal dari basaha Arab yang bentuk mufradnya adalah khuluqun (خُشَقِ) yang menurut logat diartikan budi pekerti, perangai, tingkah laku atau tabiat. Kalimat ini mengandung segi-segi persesuaian dengan perkataan khalqun(خَخَّق berarti kejadian, serta erat hubungannya

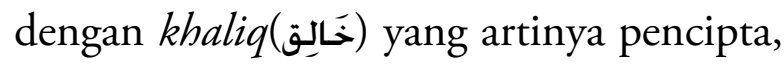

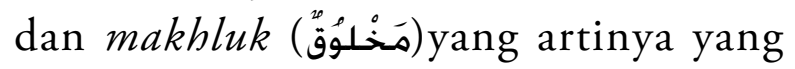

diciptakan.Alghazali menerangkan bahwa khuluq adalah suatu kondisi dalam jiwa yang suci dan dari kondisi itu tumbuh suatu aktifitas yang mudah dan gampang tanpa memerlukan pemikiran dan pertimbangan terlebih dahulu (Ahmad Mu'adz Haqqi, 2012: 510).

Pendidikan karakter adalah upaya penanaman nilai-nilai karakter kepada anak didik yang meliputi pengetahuan, kesadaran atau kemauan, dan tindakan untuk melaksanakan nilai-nilai kebaikan dan kebajikan, kepada Tuhan Yang Maha Esa, diri sendiri, sesama, lingkungan maupun kebangsaan agar menjadi manusia yang berakhlak.(Mahjudin, 2004: 7) Konteks Kajian Pusat Pengkajian Pedagogik (P3) mendefinisikan pendidikan karakter dalam setting sekolah pembelajaran yang mengarah pada penguatan dan pengembangan perilaku anak secara utuh yang didasarkan pada suatu nilai tertentu yang dirujuk oleh sekolah. Defenisi ini mengandung makna: (1) pendidikan karakter merupakan pendidikan yang terintegrasi dengan pembelajaran yang terjadi pada semua mata pelajaran, (2) diarahkan pada penguatan dan pengembangan perilaku anak secara utuh, (3) penguatan dan pengembangan perilaku didasari oleh nilai yang dirujuk sekolah.(Dharma Kusuma, 2015: 5).

Menurut Megawangi pendidikan karakter adalah sebuah usaha untuk mendidik anakanak agar dapat mengambil keputusan dengan bijak dan mempraktikkannya dalam 
kehidupan sehari-hari, sehingga mereka dapat memberikan kontribusi yang positif kepada lingkungannya.(Dharma Kusuma, 2015: 5).

Menurut pandangan Notonegoro dalam Sajarkawi (2006: 20) terdapat tiga nilai yang perlu diperhatikan serta menjadi pegangan masyarakat Indonesia yaitu; (1) Nilai materil adalah segala sesuatu yang berguna bagi unsur kehidupan manusia. (2) Nilai vital adalah sesuatu yang berguna bagi manusia untuk dapat dapat melaksanakan kegiatan atau aktifitas sehari-hari. (3) Nilai kerohanian adalah segala sesuatu yang berguna bagi rohani manusia.

Ada 18 nilai-nilai karakter yang dikembangkan Kementerian Pendidikan Nasional. Nilai-nilai yang dikembangkan dalam pendidikan karakter bangsa diidentifikasi dari sumber-sumber berikut yaitu: a) Agama, b) Pancasila, c) Buadaya, dan d) Tujuan Pendidikan Nasional.

Dari sumber-sumber di atas, dikembangkan 18 nilai-nilai dalam pendidikan karakter bangsa, sebagaimana dalam tabel berikut ini:

Tabel 1: 18 Nilai dan deskripsi nilai pendidikan karakter bangsa

\begin{tabular}{|c|c|c|}
\hline No & Nilai & Deskripsi \\
\hline 1 & Religious & $\begin{array}{l}\text { Sikap dan perilaku yang patuh dalam melaksanakan ajaran agama yang dianutnya, toleran terhadap } \\
\text { pelaksanaan ibadah agama lain, dan hidup rukun dengan pemeluk agama lain. }\end{array}$ \\
\hline 2 & Jujur & $\begin{array}{l}\text { Perilaku yang didasarkan pada upaya menjadikan dirinya sebagai orang yang selalu dapat dipercaya dalam } \\
\text { perkataan, tindakan, dan pekerjaan. }\end{array}$ \\
\hline 3 & Toleransi & $\begin{array}{l}\text { Sikap dan tindakan yang menghargai perbedaan agama, suku, etnis, pendapat, sikap dan tindakan orang } \\
\text { lain yang berbeda dengan dirinya. }\end{array}$ \\
\hline 4 & Disiplin & Tindakan yang menunjukkan perilaku tertib dan patuh pada berbagai ketentuan dan peraturan \\
\hline 5 & Kerja Keras & $\begin{array}{l}\text { Perilaku yag menunjukkan upaya sunguh-sungguh dalam mengatasi berbagai hambatan belajar dan tugas, } \\
\text { serta menyelesaikan tugas dengan sebaik-baiknya. }\end{array}$ \\
\hline 6 & Kreatif & Berfikir dan melakukan sesuatu untuk menghasilkan cara atau hasil baru dari sesuatu yang telah dimiliki. \\
\hline 7 & Mandiri & Sikap dan perilaku yang tidak mudah tergantung pada orang lain dalam menyelesaikan tugas-tugas. \\
\hline 8 & Demokratis & Cara berfikir, bersikap dan bertindak yang menilai sama hak dan kewajiban dirinya dan orang lain. \\
\hline 9 & Rasa Ingin Tahu & $\begin{array}{l}\text { Sikap dan tindakan yang selalu berupaya untuk mengetahui lebih mendalam dan meluas dari sesuatu } \\
\text { yang dipelajarinya, dilihat dan didengar. }\end{array}$ \\
\hline 10 & $\begin{array}{l}\text { Semangat } \\
\text { Kebangsaan }\end{array}$ & $\begin{array}{l}\text { Cara berpikir, bertindak dan berwawasan yang menempatkan kepentingan bangsa dan Negara di atas } \\
\text { kepentingan diri dan kelompoknya. }\end{array}$ \\
\hline 11 & Cinta Tanah Air & $\begin{array}{l}\text { Cara berfikir, bersikap, dan berbuat yang menunjukkan kesetiaan, kepedulian dan penghargaan yang } \\
\text { tinggi terhadap bahasa, lingkungan fisik, sosial, budaya, ekonomi dan politik bangsa. }\end{array}$ \\
\hline 12 & $\begin{array}{l}\text { Menghargai } \\
\text { Prestasi }\end{array}$ & $\begin{array}{l}\text { Sikap dan tindakan yang mendorong dirinya untuk menghasilkan sesuatu yang berguna bagi masyarakat } \\
\text { dan mengakui serta menghormati keberhasilan orang lain. }\end{array}$ \\
\hline 13 & $\begin{array}{l}\text { Bersahabat/ } \\
\text { Komunikatif }\end{array}$ & Tindakan yang memperlihatkan rasa senang berbicara, bergaul dan bekerja sama dengan orang lain. \\
\hline 14 & Cinta Damai & Sikap, perkataan dan tindakan yang menyebabkan orang lain merasa senang dan aman atas kehadiran dirinya. \\
\hline 15 & $\begin{array}{l}\text { Gemar } \\
\text { Membaca } \\
\end{array}$ & $\begin{array}{l}\text { Kebiasaan menyediakan waktu untuk membaca berbagai bacaan yang memberikan kebajikan bagi } \\
\text { dirinya. }\end{array}$ \\
\hline 16 & $\begin{array}{l}\text { Peduli } \\
\text { Lingkungan }\end{array}$ & $\begin{array}{l}\text { Sikap dan tindakan yang selalu berupaya mencegah kerusakan pada lingkungan alam di sekitarnya dan } \\
\text { mengembangkan upaya-upaya untuk memperbaiki kerusakan alam yang sudah terjadi. }\end{array}$ \\
\hline 17 & Peduli Sosial & $\begin{array}{l}\text { Sikap dan tindakan yang selalu ingin member bantuan pada orang lain dan masyarakat yang } \\
\text { membutuhkan. }\end{array}$ \\
\hline 18 & Tanggung Jawab & $\begin{array}{l}\text { Sikap dan perilaku seseorang untuk melaksanakan tugas dan kewajibannya, yang seharusnya dia lakukan, } \\
\text { terhadap diri sendiri, masyarakat, lingkungan (alam, sosial dan budaya) Negara dan Tuhan Yang Maha Esa. }\end{array}$ \\
\hline
\end{tabular}

Sumber: Kemendiknas, 2010: 9-10 
Karakter dibentuk melalui pengembangan unsur-unsur harkat dan martabat manusia yang secara keseluruhan bersesuaian dengan nilai-nilai luhur pancasila. Lebih rinci harkat dan martabat manusia (HMM) meliputi tiga komponen dasar yaitu:

a. Hakikat Manusia, meliputi lima unsur, yaitu bahwa manusia diciptakan sebagai makhluk yang beriman dan bertaqwa paling sempurna, paling tinggi derajatnya, khalifah di muka bumi dan penyandang hak asasi manusia.

b. Dimensi Manusia, meliputi lima dimensi, yaitu dimensi kefitrahan, dimensi keindividualan, dimensi kesosialan, dimensi kesusialaan, dan dimensi keberagaman. Penampilan kelima unsur dimensi kemanusiaan dalam kehidupan sehari-hari akan mencerminkan karakter yang bersangkutan.

c. Pancadaya Kemanusiaan, meliputi lima potensi dasar, yaitu daya taqwa, daya cipta, daya rasa, daya karsa dan daya karya. Melalui pengembangan seluruh unsur pancadaya inilah pribadi berkarakter dibangun. (Prayitno dan Belferik Manullang (ed), 2010: 38-39).

Arifin (1990: 10)memberikan defenisi Pendidikan Islam merupakan memberikan kemampuan seseorang untuk memimpin kehidupannya sesuai dengan cita-cita Islam, karena nilai-nilai Islam telah menjiwai dan mewarnai corak kepribadiannya.
Menurut Ahmad D, Marimba Pendidikan Islam adalah bimbingan jasmani, rohani berdasarkan hukum-hukum agama Islam menuju kepada terbentuknya kepribadian utama menurut ukuran-ukuran Islam. Dengan pengertian yang lain seringkali beliau mengatakan kepribadian utama tersebut dengan istilah kepribadian muslin, yaitu kepribadian yang memiliki nilai-nilai agama Islam, memilih dan memutuskan serta berbuat berdasarkan nilai-nilai Islam, dan bertanggung jawab sesuai dengan nilainilai Islam. (Hj.Nur Uhbiyati, 1987: 10).

Pendidikan Agama Islam pada umumnya dipahami sebagai mata pelajaran yang terdiri dari bidang Al-qur'an/Hadis, Akidah/Akhlak, Fikih, dan Sejarah Kebudayaan Islam. Seluruh bidang ilmu tersebut pada dasarnya adalah bersumber pada Al-qur'an dan Sunnah atau dalil-dalil naqli yang dilengkapi dengan dalil-dalil 'aqli dalam batas-batas yang tidak bertentangan dengan dalil naqli, yaitu tidak bertentangan dengan nilai-nilai keimanan, ketaqwaan, ibadah dan akhlak manusia. Dengan demikian, bahwa inti Pendidikan Agama Islam itu sesungguhnya pendidikan tentang keimanan dan ketakwaan yang transforatif, yaitu bukan keimanan yang semata-semata untuk Tuhan, tetapi keimana untuk Tuhan (ikhlas) semata-mata karena Allah, namun hasilnya tercermin dalam keyakinan, ucapan dan perbuatan. Dengan kata lain, iman yang dikehendaki adalah iman yang mampu membina hubungan yang seimbang dan harmonis antara manusia dengan Tuhan, dan antara manusia dengan 
manusia. Iman yang mempengaruhi berbagai aktivitas kehidupan manusia dalam segala bidang, termasuk dalam membangun kebudayaan dan peradaban.(Abudin Nata, 2014: 351-352).

Bachri, S Bakhtiar (2005: 10) mengemukakan bercerita adalah menuturkan sesuatu yang mengisahkan tentang perbuatan atau sesuatu kejadian dan disampaikan secara lisan dengan tujuan membagikan pengalaman dan pengetahuan kepada orang lain.Sedangkan menurut Abdul Aziz Abdul Majid (2001: 8) adalah satau bentuk sastra yang memiliki keindahan dan kenikmatan tersendiri serta merupakan sebuah bentuk sastra yang bisa dibaca atau hannya di dengar oleh orang yang tidak membaca.

Muhammad Said Mursy (2001: 117) mengemukakan cerita adalah pemaparan pengetahuan kepada anak kecil dengan gaya bahasa yang sederhana dan mudah di pahami. Sedangkan menurut Werkanis dan Marlius Hamdi (2005: 55-57) metode bercerita adalah metode penyampaian pelajaran dengan cara bercerita. Pelaksanaan metode bercerita dalam proses belajar mengajar dilakukan dengan berbagai cara, karena siswa terdiri atas berbagai lingkungan yang berbeda, baik dari segi penguasaan, kemampuan daya tangkap dan motivasi dalam mendengarkan cerita.

Bercerita dapat dijadikan metode untuk menyampaikan nilai-nilai yang berlaku dalam masyarakat. Dalam cerita atau dongeng dapat ditanamkan berbagai macam nilai moral, nilai agama, nilai sosial, nilai budaya, dan sebagainya.(Otib Satibi Hidayat, 2000: 12). Dalam cerita atau dongeng dapat ditanamkan berbagai macam nilai moral, nilai agama, nilai sosial, nilai budaya, dan sebagainya.

Dalam dunia pendidikan Islam, metode bercerita dibagi menjadi dua yaitu: (Armai Arief, 2002: 162)

\section{a. Cerita Qur'ani}

Metode cerita qur'ani adalah suatu cara Allah Swt mendidik umat agar beriman kepada-Nya dengan mempelajari dan menelaah kisah-kisah Al-qur'an secara benar. Adapun ayat yang berkaitan dengan metode cerita sebagai sarana mendidik umat adalah terdapat dalam Q.S Yusuf: 111.

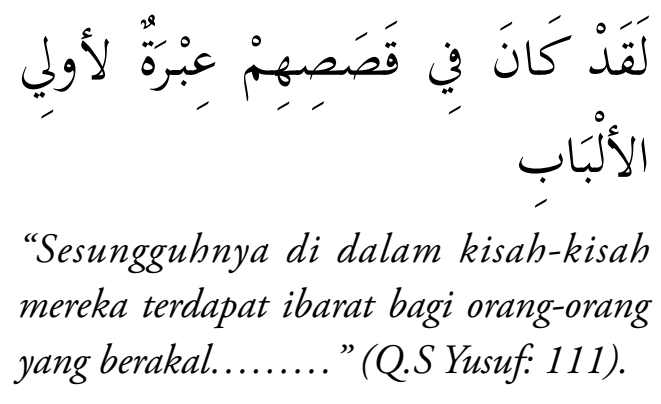

\section{b. Cerita Nabawiyah}

Kisah Nabawiyah yang didasarkan pada cerita-cerita dalam hadits Nabi Muhammad S.a.w, cenderung berisi yang lebih khusus seperti menjelaskan pentingnya keikhlasan beramal, menganjurkan bersedekah dan mensyukuri nikmat Allah.(Ahmad Tafsir, 2000: 141) Cerita nabawi berarti berdasarkan pada hadits-hadits rasul.

Isjoni (2011: 78) mengemukakan pertumbuhan dan perkembangan jasmani 
serta rohani seseorang tidak terlepas dari proses belajar (pendidikan). Menurut Piaget proses belajar harus disesuaikan dengan tahap perkembangan kognitif yang dilalui anak. Ada empat tahapan yaitu: (1) tahap sensori-motor, (2) tahap pra-operasional, (3) tahap operasional kongkrit, dan (4) tahap operasional formal.

Bercerita mempunyai makna penting bagi perkembangan anak, karena melalui cerita kita dapat (Isjoni, 2011: 90-91): (a) mengkomunikasikan nilai-nilai budaya, (b) mengkomunikasikan nilai-nilai sosial, (c) mengkomunikasikan nilai-nilai keagamaan, (d) menanamkan etos kerja, waktu, alam, (e) membantu mengembangkan fantasi anak, (f) membantu mengembangkan dimensi kognitif anak, (g) membantu mengembangkan dimensi bahasa anak.

Bagi anak mendengarkan cerita yang menarik yang dekat dengan lingkungannya merupakan kegiatan yang mengasyikkan. Guru/pencerita dapat memanfaatkan kegiatan bercerita untuk menanamkan kejujuran, keberanian, kesetiaan, keramahan, ketulusan dan sikap-sikap positif yang lain dalam kehidupan lingkungan keluarga, sekolah dan luar sekolah.(Moeslichatoen, 1996: 152) Di samping itu, juga guru/pencerita melalui bercerita dapat meningkatkan daya serap atau daya tangkap anak, melatih konsentrasi anak, serta mengembangkan daya imajinasi anak artinya dengan bercerita anak dapat membayangkan atau menggambarkan suatu situasi yang berada di luar jangkauan inderanya bahkan yang mungkin jauh dari lingkungan sekitarnya.

Perkembangan kognitif dan perilaku anak yang lebih komplek disebabkan, karena perkembangan otak dan sistem saraf anak yang berkembang lebih baik. Otak manusia terdiri dari dua bagian, yaitu belahan otak kanan dan belahan otak kiri yang bersifat lateral. Lateralisasi mengacu pada lokasilisasi berbagai macam fungsi, kompetensi, dan keterampilan dalam salah satu atau kedua belahan otak.(Dhieni Nurbiana, 2008: 66)

Roger W. Sperry, berdasarkan penelitiannya menemukan bahwa otak manusia memiliki pengkhususan fungsi pada belahan otak kanan dan kiri, sehingga menyebabkan masing-masing otak mempunyai tugas yang berbeda satu sama lainnya.(Daniel H. Pink, 2010: 27) Perbedaan fungsi kedua belahan otak atau hemisfer tersebut dapat dilihat pada tabel di bawah ini:

Tabel 2: Perbedaan fungsi otak kiri dan kanan

\begin{tabular}{|l|l|}
\hline \multicolumn{1}{|c|}{ Otak (hemisfer) kiri } & \multicolumn{1}{|c|}{ Otak (hemisfer) kanan } \\
\hline - Lebih mempunyai & - Lebih luas asosiasi visualnya \\
representasi-representasi & • Berfungsi untuk \\
sensoris dan motoris & penyadaran dan pengenalan \\
- Lebih bisa menguasai & pola-pola. \\
informasi temporal. & - Berperan penting dalam \\
- Dalam hal pengaturan & mengenal gambar, \\
waktu, member urutan & membayangkannya secara \\
pada sesuatu dan soal-soal & mental, juga mengolahnya \\
pembagian. & di ruang. \\
- Bekerja lebih analitis, lebih & - Mempunyai konsentrasi \\
memperhatikan detail. & noradrenalin yang dapat \\
- Bereaksi kepada penjelasan & mempengaruhi pengarahan \\
dan instruksi verbal & perhatian dan serotonin \\
- Kurang mahir dalam & lebih besar yang berperan \\
menangkap bahasa gerak & aktif dalam menentang \\
& depresi dan perasaan takut. \\
& (Reni I.I Dharmaperwira- \\
& Prins, 2004: 15-16) \\
\hline
\end{tabular}




\begin{tabular}{|l|l|}
\hline - Lebih suka berbicara dan & - Member reaksi terhadap \\
menulis & contoh, ilustrasi, dan \\
- Mencoba secara sistematis & - Simbol dan bentuk dipakai \\
dan terkendali & untuk menata logika \\
- Perasaan terkendali & - Melukis dan mengatur \\
- Lebih suka memakai logika & benda \\
dalam menyelesaikan & - Mencoba secara acak dan \\
masalah & longgar \\
& - Bebas/spontan dengan \\
& perasaan \\
& - Mahir mengerti simbol \\
& - Intuisi dipakai untuk \\
& menyelesaikan masalah. \\
& (Arif Rohman, 2006: 52) \\
\hline
\end{tabular}

Menurut beberapa ahli pendidikan, tujuan penggunaan metode cerita dalam pendidikan adalah sebagai berikut:

\section{1) Ahmad Tafsir}

Menurut Ahmad Tafsir (2000: 142) tujuan kisah Qur'ani adalah:

a) Menggunakan kemantapan wahyu dan risalah Allah

b) Menjelaskan secara keseluruhan alDin yang datang dari Allah

c) Menjelaskan pertolongan dan kecintaan Allah pada Rasul-Nya serta kaum mu'min.

d) Menguatkan keimanan kaum muslim

e) Menunjukkan permusuhan abadi kaum muslimin dengan syaitan.

Sedangkan tujuan kisah Nabawiyah adalah:

a. Menjelaskan pentingnya berbuat amaliah

b. Memberikan tauladan yang baik dari Nabi Saw.

c. Memberikan wacana dalam bersikap positif terhadap diri dan lingkungan d. Menganjurkan untuk mensyukuri nikmat Allah.

\section{2) Abdul 'Aziz' Abdul Majid}

Menurut Abdul Aziz Abdul Majid (2002: 81), tujuan penceritaan adalah sebagai berikut, a) Untuk menghibur siswa, b) Menambah wawasan agama, c) Menambah perbendaharaan bahasa dan kosa kata, d) Menumbuhkembangkan daya imajinasi anak, e) Membersihkan cita rasa (feeling), dan f) Melatih siswa mengungkapkan ide.

Menurut Bachri (2005: 11) manfaat bercerita adalah dapat memperluas wawasan dan cara berfikir anak, sebab dalam bercerita anak mendapat tambahan pengalaman yang bisa jadi merupakan hal baru baginya.

Tampubulon(1991: 11) menjelaskan hal-hal yang harus diperhatikan oleh guru dalam menyampaikan cerita, yaitu:

a. Pertama, saat persiapan, memilih materi cerita. Sebuah cerita yang berhubungan dengan tema atau topik pembelajaran, baik cerita yang sudah terjadi atau yang sedang hangat diceritakan orang atau diberitakan oleh media. Kemudian, kuasai alur ceritanya dengan baik.

b. Kedua, Pengelolaan kelas untuk bercerita yang terdiri dari Pengorganisasian siswa, penugasan kelas, disiplin kelas dan pembimbingan siswa

c. Ketiga,Pengelolaan tempat untuk bercerita yang terdiri daripenataan tempat untuk bercerita, posisi media, penataan ruang cerita 
d. Keempat, Strategi penyampaian yang terdiri dari:

e. Strategi storytelling, merupakan penceritaan cerita yang dilakukan secara terencana dengan menggunakan boneka, atau benda-benda visual, metode ini bertujuan untuk menghasilkan kemampuan berbahasa anak.

f. strategi reproduksi ceritaadalah kegiatan belajar mengajar bercerita kembali cerita yang didengar

g. strategi simulasi kreatif dilaksanakan untuk memanipulasi kegiatan belajar sambil bermain dari penggalan dialog cerita atau bermain peran membawakan tokoh-tokoh dalam cerita.

Teknik penggunaan metode bercerita yaitu: a) teknik bercerita menggunakan alat peraga, b) teknik bercerita menggunakan gambar, dan c) teknik bercerita tanpa menggunakan alat peraga.

\section{a. Teknik bercerita menggunakan alat peraga}

Dalam melaksanakan kegiatan bercerita digunakan alat peraga untuk memberikan kepada anak didik suatu tanggapan yang mengenai hal-hal yang di dengar dalam cerita. Alat peraga dalam pengertian ini adalah beberapa jenis hewan atau bendabenda yang sebenarnya, bukan tiruan atau berupa gambar-gambar. Penggunaan alat peraga langsung untuk memberikan kepada anak suatu tanggapan yang tepat mengenai hal-hal yang di dengar melalui cerita.
Eddy Supriadi (2003: 13)langkah-langkah metode bercerita dengan menggunakan alat peraga, yaitu sebagai berikut:

1. Alat peraga diperhatikan dan diperkenalkan terlebih dahulu pada peserta didik.

2. Guru menjelaskan dengan singkat melalui tanya jawab dengan mengenalkan objek yang akan diceritakan.

3. Alat peraga kemudian disimpan sebelum guru bercerita dan mengatur posisi duduk peserta didik.

\section{b. Teknik bercerita menggunakan gambar}

Bercerita dengan gambar hendaknya sesuai dengan tahap perkembangan anak, isinya menarik, mudah dimengerti dan membawa pesan, baik dalam hal pembentukan perilaku positif maupun pengembangan kemampuan dasar.Eddy Supriadi (2003: 13)hal-hal yang perlu diperhatikan dalam bercerita dengan gambar adalah:

1. Gambar harus jelas dan tidak terlalu kecil

2. Guru memperhatikan gambar tidak terlalu tinggi dan harus terlihat

3. Gambar-gambar yang digunakan harus menarik

4. Gambar yang ditutup setiap kali guru memulai kembali.

\section{c. Teknik bercerita tanpa menggunakan alat peraga}

Kegiatan bercerita dengan teknik bercerita tanpa menggunakan alat peraga, 
yang berperan adalah guru dengan cara bercerita melalui ekspresi yang tepat. Dalam menggunakan teknik ini ada beberapa hal yang perlu diperhatikan di antaranya adalah sebagai berikut:

1. Guru harus menunjukkan mimic muka, gerakan-gerakan tangan dan kaki serta suara sebagai pencerminan dan penghayatan secara sunguh-sungguh terhadap isi dan alur cerita.

2. Dalam bercerita harus menggunakan bahasa yang jelas, komunikasi dan mudah dimengerti anak

3. Sebelum bercerita aturlah posisi duduk anak dan guru

4. Selama bercerita hindari teguran pada anak.

Pengaruh cerita lebih besar dari pada memberikan pengajaran semata-mata dengan nasehat atau menyuruh dan melarang kepada anak atau peserta didik. (Mahmud Yunus, 1983: 19)

Beberapa langkah pelaksanaan metode cerita menurut beberapa ahli pendidikan adalah sebagai berikut:

1. Menurut Verna Hildebrand (1971: 187), langkah-langkah pelaksanaan metode cerita adalah:

a. Choosing a Story, yaitu pemilihan cerita sesuai dengan situasi dan kondisi proses belajar mengajar.

b. Size of Story Group, yaitu pengorganisasian kelompok cerita, semakin sedikit jumlah anggota dalam kelompok penceritaan semakin efektif proses dan hasilnya.

c. Chair or Floor for Story time, yaitu penataan posisi tempat duduk siswa yang biasanya dilakukan diatas kursi/ lantai dengan informasi setengah lingkaran.

d. Transition to Story Time, yaitu perubahan dalam penceritaan yang merangsang aktivitas siswa untuk mendengarkan penceritaan dengan perilaku.

\section{Kelebihan Metode Cerita}

Menurut Suyanto (2006: 193) ada beberapa kelebihan dan kelemahan dari metode bercerita, berikut ini:

1) Dengan mendengarkan cerita, kepekaan jiwa dan perasaan siswa tergugah.

2) Melatih daya konsentrasi siswa.

3) Melatih daya fikir dan daya fantasi siswa.

4) Menambah pengetahuan siswa.

5) Secara otomatis mendorong siswa untuk berbuat kebajikan berdasarkan cerita yang disampaikan.

6) Organisasi kelas lebih sederhana, tidak perlu pengelompokansiswa seperti pada metode lain.

7) Guru dapat menguasai kelas dengan mudah walaupun siswadalam jumlah yang cukup besar apabila cerita yang disampaikan mampu menarik perhatian siswa.

8) Bila guru dalam bercerita berhasil dengan baik, maka dapatmenimbulkan semangat, kreasi yang konstruktif dan bisamerangsang para siswa untuk 
melakukan tugas ataupekerjaan.

9) Metode ini lebih fleksibel dalam arti jika waktu terbatasmateri cerita dapat dipersingkat dengan mengambil garis besarnya saja, jika waktu yang tersedia cukup banyak matericerita yang diberikan dapat diperluas dandiperdalam.

\section{Kelemahan Metode Cerita}

1) Guru sulit mengetahui sampai dimana batas kemampuansiswa dalam memahami materi cerita yang disampaikan.

2) Para siswa lebih cenderung bersifat pasif dan menganggapbahwa yang diceritakan itu benar.

3) Guru dalam bercerita sering tidak memperhatikan segipsikologis dan didaktis, pembicaraan dapat tidak terarahsehingga membosankan para siswa, atau kadang terlalubanyak humor sehingga tujuan utamanya terabaikan.

\section{METODE}

Penelitian ini dilakukan dengan menggunakan penelitian lapangan (field research), yang bersifat deskriptif kualitatif, yaitu suatu penelitian yang mengungkapkan serta menggambarkan kejadian yang terjadi di lapangan sebagaimana adanya di lokasi penelitian ini dilakukan.Secara holistik dengan deskripsi dalam bentuk kata-ata dan bahasa, pada suatu konteks khusus yang alamiah dan dengan memanfaatkan berbagai metode alamiah.(Lexy Maleong, 2004: 6)
Nana Syaodih Sukmadinata (2010: 12) menyatakan berdasarkan pendekatan, secara garis besar dibedakan dalam dua macam penelitian, yaitu pendekatan kuantitatif dan pendekatan kualitatif. Kedua pendekatan ini memiliki perbedaan, perbedaan yang paling mendasar adalah pendekatan kualitatif menggunakan strategi dan prosedur penelitian yang fleksibel.

Sejalan dengan pendapat di atas, menjelaskan bahwa penelitian kualitatif adalah sebuah penelitian untuk memahami fenomena tentang apa yang dialami oleh subjek peneliti secara holistik dan dengan cara deskripsi dalam bentuk kata-kata dan bahasa. (Lexy Maleong, 2004: 7)

Dalam penelitian ini, cara pengambilan subjek penelitian adalah dengan purposive. Suharsimi Arikunto (1993: 183) menjelaskan bahwa dalam purposive, cara mengambil subjek penelitian bukan didasarkan atas strata, random, atau daerah tetapi didasarkan atas adanya tujuan tertentu.Sumber data merupakan segala yang bisa memberikan informasi mengenai data. Berdasarkan sumbernya, data dikelompokkan atas dua macam data, yaitu data primer dan data sekunder.

Untuk mengungkapkan proses penanaman nilai-nilai karakter dalam Pendidikan Agama Islam melalui metode bercerita di SD N 07 Sumanik, sumber data yang peneliti gunakan terdiri dari dua macam: 1. Sumber data utama (primer), yaitu sumber data yang langsung memberikan data 
kepada pengumpul data. Dalam hal ini, data primer adalah data yang diperoleh dan dikumpulkan secara langsung dari informen melalui pengamatan dan wawancara, sumber data ini di dapatkan dari guru PAI di SD N 07 Sumanik ditambah siswa.

2. Sumber data tambahan (sekunder), merupakan sumber data yang tidak langsung memberikan data kepada pengumpul data, misalnya lewat orang lain atau lewat dokumen.

Sedangkan yang menjadi obyek penelitian adalah penelitian Penanaman Nilai-Nilai Karakter dalam Pendidikan Agama Islam Pada peserta didik Melalui Metode Bercerita yang di lakukan di SDN 07 Sumanik Nagari Sumanik Kecamatan Salimpaung.

Teknik pengumpulan data yang digunakan adalah observasi, wawancara dan studi dokumentasi. Observasi adalah pengamatan secara langsung dan pencatatan secara cermat serta sistematis terhadap fenomena-fenomena yang terjadi di lapangan yang diteliti. (Suharsimi Arikunto, 1993: 113)Wawancara adalah suatu bentuk komunikasi verbal yang bertujuan untuk memperoleh informasi yang jelas dan diinginkan.(S. Nasution, 2006: 113) Dalam penelitian ini peneliti menggunakan teknik wawancara mendalam. Indepth interview (wawancara mendalam) adalah metode wawancara yang memungkinkan pihak yang diwawancarai untuk mendefinisikan dirinya sendiri dan lingkungannya, untuk menggunakan istilah - istilah mereka sendiri mengenai fenomena yang diteliti, tidak sekedar menjawab pertanyaan.(Deddy Mulyana, 2004: 183) Dalam penelitian ini wawancara digunakan untuk mengetahui proses pelaksanaan penanaman nilai-nilai karakter dalam Pendidikan Agama Islam melalui metode bercerita. Adapun peneliti melakukan wawancara mendalam dengan subjek penelitian di atas.

Dokumentasi digunakan dalam rangka mencari dan mengumpulkan data berupa dokumen atau data tertulis lain yang menginformasikan keadaan riil sekarang. (Burhan Bungin, 2001: 178) Pengumpulan data melalui dokumentasi ini merupakan metode pengumpulan data dengan cara mencari data mengenai hal-hal atau varibael berupa catatan, surat-surat, dokumendokumen dan lainnya.(Suharsimi Arikunto, 1993: 206)

Analisis data adalah suatu proses pengklasifikasian, pengkategorian, penyusunan dan elaborasi, sehingga data yang telah terkumpul dapat diberikan makna untuk menjawab masalah penelitian yang telah dirumuskan atau untuk mencapai tujuan penelitian yang telah dirumuskan atau untuk mencapai tujuan penelitian. Berdasarkan jenis penelitian yang bersifat kualitatif, maka analisa data berlangsung selama dan pasca tahap penarikan kesimpulan hasil studi.

Penanaman Nilai-Nilai Karakter dalam Pendidikan Agama Islam... 
Proses-proses analisa kualitatif tersebut dapat dijelaskan ke dalam 3 langkah berikut:

\section{Reduksi Data}

Reduksi data adalah proses pemilihan, pemusatan perhatian pada penyederhanaan, abtraksi dan transformasi data kasar yang diperoleh dilapangan.(Agus Salim, 2006: 22)

Pada proses reduksi data ini peneliti akan menyeleksi data dari hasil wawancara, observasi dan studi dokumentsi, dengan cara menfokuskan pada data yang lebih menarik, penting, berguna dan baru. Data yang dirasa tidak penting disingkirkan. (Sugiyono, 2011: 338)

2. Penyajian Data

Setelah data direduksi, maka langkah selanjutnya adalah mendisplaykan data. Display data merupakan proses mendiskripsikan kumpulan informasi secara sitematis dalam bentuk susunan yang jelas untuk membantu peneliti mengalisa hasil penelitian.(2011: 339) Untuk memudahkan penyajian data ini peneliti membuat catatan lapangan dalam bentuk teks naratif untuk memudahkan penguasaan informasi atau data yang dimaksud.

3. Penarikan Kesimpulan dan Verifikasi Penarikan kesimpulan dan verifikasi merupakan kegiatan interpretasi, dengan maksud untuk menemukan makna dari data yang telah disajikan, misalnya dengan menghubung-hubungkan antara data satu dengan yang lain.

Kesimpulan data dilakukan secara sementara, kemudian diverifikasikan dengan cara mencaru data yang lebih mendalan dengan mempelajari hasil data yang telah terkumpul.(Mathew B. Milles \& A. Michel Hubermen, 1992: 16) Pengecekan informasi atau data dapat dilakukan oleh setiap peneliti sekesai wawancara, ditempuh dengan mengkonformasikan hasil wawancara dengan responden.

Komponen-komponen analisis data (yang mencakup reduksi, penyajian data, dan penrikan kesimpulan) secara interaktif saling berhubungan selama dan sesudah pengumpulan data. Atas dasar tersebut karakter analisis data kualitatif disebut model interaktif.

Komponen analisis data dapat digambarkan sebagai berikut:

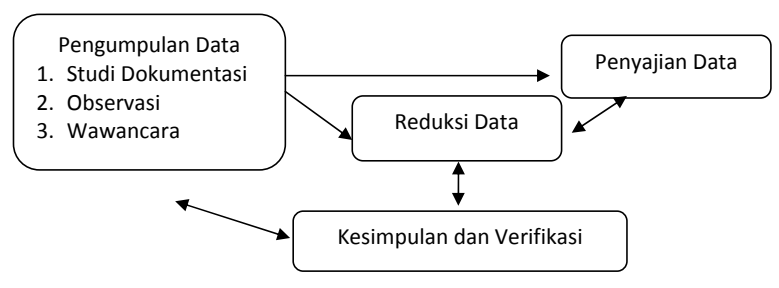

Sumber: Sugiyono, metode Penelitian Pendidikan, Bandung: Alfabeta, 2011, hlm 338 .

Triangulasi yang digunakan peneliti guna meningkatkan keabsahan data adalah triangulasi sumber dimana peneliti membandingkan dan mengecek balik derajat kepercayaan suatu informasi yang diperoleh melalui waktu dan alat yang berbeda dalam 
penelitian kualitatif.

Dalam triangulasi sumber, peneliti melakukan pengecekan dengan cara membandingkan data hasil wawancara dengan data hasil observasi, membandingkan apa yang diucapkan oleh guru dengan kegiatan yang ia lakukan selama proses pembelajaran berlangsung, dan membandingkan hasil observasi, wawancara dengan dokumentasi yang berkaitan dengan topik permasalahan.

Ini sependapat dengan Moleong (2004: 330) yang menyatakan bahwa triangulasi merupakan teknik pemerikasaan keabsahan data yang memanfaatkan sesuatu lain dari luar untuk keperluan pengecekan atau sebagai pembanding terhadap data-data tersebut.

\section{HASIL DAN PEMBAHASAN}

Pada pembahasan ini peneliti akan memaparkan hasil penelitian berdasarkan hasil wawancara dan observasi yang dilakukan pada guru PAI SD N 07 Sumanik Nagari Sumanik Kecamatan Salimpaung tentang penanaman nilai-nilai karakter dalam pendidikan agama Islam melalui metode bercerita. Untuk lebih jelasnya peneliti akan memaparkan hasil penelitian sebagai berikut:

\section{Proses Pelaksanaan Metode Bercerita Dalam Pendidikan Agama Islam di SD N 07 Sumanik Nagari Sumanik Kecamatan Salimpaung}

Dari hasil observasi terungkap dan terlihat bahwa guru PAI pada proses pembelajaran
PAI dalam menanamkan nilai-nilai karakter pada siswa melalui metode bercerita sudah baik. Guru juga sudah melaksanakan langkah-langkah metode cerita, seperti; mengatur duduk siswa (menyuruh siswa duduk kembali di tempat mereka masingmasing). Secara umum hasil observasi (pengamatan) pelaksanaan metode bercerita dalam menanamkan nilai-nilai karakter pada pembelajaran PAI dikategorikan baik, hal ini dapat peneliti amati dari observasi dalam proses pelaksanaan metode bercerita dan melalui studi dokumentasi (rekaman video pelaksanaan metode bercerita)

Hasil observasi pengamatan pelaksanaan metode bercerita dalam menanamkan nilainilai karakter pada Pendidikan Agama Islam di SD N 07 Sumanik responden dalam melaksanakan kegiatan mengatur tempat duduk siswa di kategorikan baik. Responden tidak lagi mengatur tempat duduk siswa, hannya saja responden kembali menyuruh dan mempersilahkan siswa duduk di tempat yang telah di tetapkan dan di atur oleh guru kelas.

Kegiatan guru menyampaikan tema cerita dalam pelaksanaan metode bercerita pada mata pelajaran Pendidikan Agama Islam dalam penanaman nilai-nilai karakter di kategorikan sangat baik, begitupun dengan kegiatan guru mempersiapkan cerita sebelum masuk kelas dikategorikan baik. Responden sebelum menyampaikan cerita yang telah di persiapkan, responden menyampaikan tema 
cerita yang ada hubungannya atau berkaitan dengan materi yang dipelajari.

Kegiatan guru menyampaikan cerita dengan suara yang nyaring (jelas) dan intonasi dikategorikan sangat baik. Responden dalam kegiatan pelaksanaan metode bercerita dalam menanamkan nilai-nilai karakter kepada siswa menyampaikan cerita dengan suara nyaring (keras/jelas) dan berintonasi agar cerita yang disampaikan itu menarik bagi siswa. sedangkan, pada kegiatan guru mengajukan pertanyaan kepada siswa sesuai dengan cerita di kategorikan baik. Responden mengajukan pertanyaan yang sesuai dengan cerita di awal atau sebelum menyampaikan cerita kepada siswa, akan tetapi disaat menjawab pertayaan dari responden, responden tidak menunjuk atau menentukan siswa yang akan menjawab, hannya siswa yang bisa atau di jawab secara bersama-sama oleh siswa.

Teknik metode bercerita dalam pelaksanaan metode bercerita dalam penanaman nilai-nilai karakter pada Pendidikan Agama Islam di SD N 07 Sumanik, pada kegiatan guru menggunakan teknik bercerita dengan menggunakan alat peraga di kategorikan tidak baik, begitpun dengan kegiatan bercerita menggunakan media gambar di kategorikan tidak baik, sedangkan pada kegiatan bercerita dengan tanpa menggunakan alat peraga dan media gambar di kategorikan sangat baik. Dalam hal ini menandakannya responden tersebut lebih dominan dalam melaksanakan metode bercerita menggunakan teknik bercerita tanpa alat peraga maupun media gambar, dalam artian responden memang lebih mengandalkan gaya bahasa, intonasi serta mimic wajah dalam menyampaikan cerita, ketimbang dengan menggunakan alat peraga dan media gambar.

Pelaksanaan metode bercerita pada kegiatan guru menyuruh siswa menceritakan kembali cerita yang telah di sampaikan oleh guru sebagai salah satu bentuk evaluasi dalam metode bercerita, di sini kegiatan responden tersebut dikategorikan tidak baik. Hal ini menandakan responden belum melakukan kegiatan tersebut dengan baik, responden lebih melakukan tahap kegiatan tersebut dengan memberikan pertanyaan langsung kepada siswa yang langsung di jawab oleh siswa baik itu secara bersama atau siswa yang bisa menjawab untuk langsung menjawab, responden tidak menunjuk siswa yang akan menjawab pertanyaan tesebut. Observasi ini sama dengan pernyataan yang disampaikan oleh responden pada wawancara yang mengatakan bahwa

"Ya, Bapak ada menyuruh siswa untuk menceritakan kembali cerita yang telah Bapak sampaikan, dan terkadang Bapak melakukannya denga memberikan pertanyaan kepada dan siswa menjawab". (Wawancara dengan guru PAI)

Melalui observasi dan wawancara dengan responden dapat penulis simpulkan di sini, bahwa responden sudah melakukan kegiatan pada tahap menyuruh siswa menceritakan kembali cerita yang telah disampaikan, akan tetapi dengan cara responden memberikan 
pertanyaan kepada secara umum untuk membantu kepada siswa dalam menceritakan kembali cerita yang telah disampaikan.

\section{Penanaman Nilai-nilai Karakter pada Siswa} dalam Pendidikan Agama Islam Melalui Metode Bercerita di SD N 07 Sumanik Nagari Sumanik Kecamatan Salimpaung

Melalui observasi dapat disimpulkan bahwa nilai-nilai karakter yang di tanamkan kepada siswa dalam Pendidikan Agama Islam melalui metode bercerita, yaitu 1) religious, 2) jujur, 3) Toleransi, 4) kerja keras, 5) rasa ingin tahu, 6) semangat kebangsaan, 7) menghargai prestasi, 8) bersahabat/ komunikatif, 9) cinta damai, 10) peduli sosial, dan 11) tanggung jawab. Sedangkan nilai-nilai karakter 1) kreatif, 2) mandiri, 3) demokratis, 4) cinta tanah air, 5) gemar membaca, 6) disiplin, dan 7) peduli lingkungan belum terlihat dari cerita yang disampaikan oleh guru Pendidikan Agama Islam.

Berdasarkan observasi pengamatan dalam penanaman nilai-nilai karakter pada Pendidikan Agama Islam melalui metode bercerita di SD N 07 Sumanik dikategorikan baik. Melalui observasi dan diketahui dari tabel di atas terlihat belum seluruhnya atau ke18 nilai-nilai karakter yang ditanamkan oleh responden melalui cerita yang disampaikan. Hal ini sesuai dan diperkuat melalui wawancara dengan responden yang menyatakan:

"Ya, itu tergantung pada isi cerita yang disampaikan, kalau ada terkandung nilai-nilai karakter tersebut dan itu bapak sampaikan kepada siswa dengan memberikan penjelasan ataupun semacam ulasan penguatan kepada siswa mengenai nilai karakter tersebut". (Wawancara dengan guru PAI)

\section{PEMBAHASAN}

\section{Mengatur posisi duduk siswa}

Melalui observasi pengamatan yang dilakukan dan wawancara dengan responden dapat disimpulkan bahwa guru sebelum memulai pelaksanaan metode bercerita, telah mengatur posisi dusuk siswa. walau hannya sebatas dengan menyuruh siswa kembali duduk pada posisi semula atau duduk pada posisi yang telah ditentukan (ditetapkan) oleh guru kelas masing-masing. Dalam hal ini responden melakukan kegiatan mengatur tempat duduk siswa di kelas I s/d VI dalam bercerita untuk penanaman nilai-nilai karakter pada Pendidikan Agama Islam di SD N 07 Sumanik tergolong tidak baik, sehingga kegiatan mengatur tempat duduk siswa belum dilakukan oleh responden sebagaimana mestinya.

Ketika bercerita hendaknya para murid diposisikan secara khusus tempat duduknya, agar perhatian dan pikiran mereka dapat dipusatkan kepada guru. karena posisi tempat duduk siswa yang dekat dengan guru dapat membantu pendengaran para murid dalam menyimak, juga gerakan-gerakan (tingkah laku) siswa selama proses pembelajaran berlangsung dapat diperhatikan dengan jelas. Sehingga posisi yang demikian juga

Penanaman Nilai-Nilai Karakter dalam Pendidikan Agama Islam... $\quad$ 79 
dapat membantu guru dalam membimbing siswa.(Abdul Majid, Abdul Aziz, 2005: 47)

Posisi duduk yang baik bagi para murid dalam mendengarkan cerita adalah mengelilingi guru dengan posisi setengah lingkaran, seperti gambar di bawah ini:

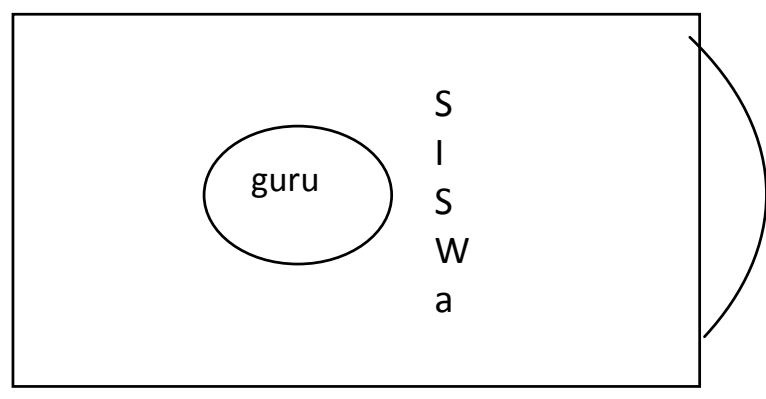

Sumber: Abdul Majid, Abdul Aziz, Mendidik Dengan Cerita, Bandung: PT. Remaja Rosdakarya, 2005, hlm. 33

Gambar: posisi tempat duduk siswa dalam bercerita

Menurut Abdul Majid Abdul Aziz (2005: 48) ada beberapa hal sebagai metode yang diperhatikan oleh guru dalam bercerita meliputi: a) tempat bercerita, b) posisi duduk, c) bahasa cerita, d) intonasi guru, e) pemunculan tokoh-tokoh, f) penampakan emosi, g) peniruan suara, h) penguasaan terhadap murid yang tidak serius, i) menghindari ucapan spontan.

Dalam pelaksanaan metode bercerita, peneliti berpendapat bahwa dalam proses pembelajaran Pendidikan Agama Islam melalui metode bercerita di SD N 07 Sumanik sudah sesuai dengan prosedur dan teori yang ada, walaupun masih ada yang belum sesuai dengan prosedur dan teori maupun syntak dalam pelaksanaan metode bercerita dengan teknik bercerita tanpa menggunakan alat peraga.

\section{Menyampaikan tema cerita dan mempersiapkan cerita sebelum masuk kelas}

Maksud dari menyampaikan tema cerita di sini yaitu guru menyampaikan judul cerita sesuai dengan materi pelajaran yang akan disampaikan oleh guru dalam Pendidikan Agama Islam di SD N 07 Sumanik Nagari Sumanik. Materi pelajaran merupakan suatu yang disajikan oleh guru untuk dipelajari dan kemudian di pahami oleh siswa, untuk mencapai tujuan pembelajaran yang telah di tetapkan.

Ada beberapa hal yang harus diperhatikan oleh guru dalam pelaksanaan pembelajaran Pendidikan Agama Islam melalui metode bercerita, yaitu 1) Pemilihan jenis cerita, 2) Penyiapan bahan cerita, 3) Penggunaan bahasa, 4) memposisikan diri pencerita, 5) penguasaan suara, 6) penguasaan tokoh cerita, 7) reaksi dan sikap pendegar saat bercerita. (Abdul Majid, Abdul Aziz, 2003: 61)

\section{Menyampaikan cerita dengan suara nyaring (jelas) dan intonasi}

Berdasarkan observasi dan wawancara dengan guru Pendidikan Agama Islam SD N 07 Sumanik dapat disimpulkan bahwa guru dalam menyampaikan cerita dengan suara nyaring (jelas) dan intonasi dengan baik. Maksud dari menyampaikan cerita dengan suara nyaring (jelas) dan intonasi di sini yaitu, guru menyampaikan cerita dengan suara yang jelas dan bahasa yang mudah dipahami oleh siswa, dan juga dalam saat penyampaian cerita guru menyampaikan cerita dengan suara 
yang berintonasi, dalam kata lain tidak datar. Sehingga cerita yang disampaikan kepada siswa menarik bagi mereka.

Pengucapan bahasa atau kata-kata yang disampaikan oleh guru pada saat bercerita harus baik, guru harus mampi mengartikulasikan huruf mati dan huruf hidup dengan sempurna, juga guru atau pencerita diharapkan mampu menirukan suara makhluk hidup di muka bumi ini dengan baik.(Enny Zubaidah, 2013: 308)

Selama bercerita guru hendaknya dapat mengubah intonasi suaranya. Pada awal cerita di mulai dengan suara tenang, kemudian sedikit demi sedikit guru atau pencerita mulai mengeraskan suaranya. Perubahan naik turunnya tekanan suara harus sesuai dengan peristiwa dan suasana dalam cerita. (Abdul Majid, Abdul Aziz, 2005: 49) Oleh karena itu, dalam bercerita guru harus piawai dalam mengatur intonasi pada saat bercerita. Intonasi atau nada suara adalah keras lemahnya dan tinggi rendahnya suara.(Enny Zubaidah, 2013: 308) Dengan demikian, guru sebagai pencerita hendaknya memiliki warna suara yang mampu mengubah suara tersebut dengan tidak selalu monoton, tergantung dari lakon (tokoh) yang terdapat di dalam cerita.

Menurut peneliti di sini, guru dalam menyampaikan cerita dengan suara nyaring (jelas) dan intonasi sesuai dengan teori yang ada. Guru dalam melaksanakan metode bercerita pada Pendidikan Agama Islam di SD N 07 Sumanik Nagari Sumanik sudah melakukan dengan baik, walaupun masih ada yang belum sesuai dengan teori. Dengan intonasi suara yang dilakukan, dimulai dari rendah, datar dan mulai tinggi pada saat klimaks yang sesuai dengan alur cerita, akan mampu menarik atau mengubah perhatian siswa atau pendengar cerita yang pada akhirnya cerita yang disampaikan menjadi menarik bagi siswa ataupun pendengar.

\section{Mengajukan pertanyaan kepada siswa}

Maksud dari mengajukan atau memberikan pertanyaan kepada siswa di sini adalah guru mengajukan pertanyaan kepada siswa sesuai dengan cerita sebelum memulai menceritakan isi cerita kepada siswa di dalam kelas.

Sebagai awal dalam pelaksanaan metode cerita sebelum menyampaikan isi cerita kepada siswa, guru mampu melontarkan pertanyaan-pertanyaan umum untuk merangsang kepekaan anak-anak atau siswa terhadap menu cerita yang akan disampaikan. Hal ini dapat dilakukan dengan cara menanyakan kepada anak tentang hal-hal yang akan dimunculkan dalam bercerita, misalnya siswa diajak menyanyikan lagu yang sesuai dengan tema cerita yang akan disampaikan. Dari hal-hal yang akan ditanyakan tersebut akan dapat membawa anak-anak pada menu cerita yang disampaikan.(Enny Zubaidah, 2013: 308)

Guru dalam proses pelaksanaan metode bercerita, memberikan pertanyaan-pertanyaan yang bersifat umum kepada siswa sebelum menyampaikan cerita, sebagai bentuk langkah- 
langkah pelaksanaan metode bercerita dalam penanaman nilai-nilai karakter kepada siswa di SD N 07 Sumanik, juga untuk memberikan rangsangan dan motivasi sebelum memulai cerita. Kegiatan memberikan pertanyaan ini sudah sesuai dengan prosedur dan tujuan dari metode bercerita itu sendiri.

\section{Menyampaikan cerita dengan teknik bercerita tanpa menggunakan alat peraga dan maupun media gambar.}

Berdasarkan observasi dan wawancara dengan responden dalam penanaman nilainilai karakter pada Pendidikan Agama Islam melalui metode bercerita di SD N 07 Sumanik dapat disimpulkan bahwa guru Pendidikan Agama Islam menggunakan teknik bercerita tanpa bantuan alat peraga maupun media gambar. Maksud dari teknik bercerita tanpa menggunakan alat peraga yaitu guru Pendidikan Agama Islam menyampaikan cerita tanpa menggunakan alat peraga dan maupun media gambar. Guru lebih dominan atau mengandalkan kemampuan berbahasa dan gerak tubuh, mimic wajah serta intonasi dalam menyampaikan cerita kepada siswa.

Bercerita tanpa alat peraga merupakan bentuk teknik bercerita yang tertua dan setiap anak pernah mengalami pada penceritaan dari orang tua. Hal yang paling utama adalah gerak-gerik dan suara yang menguatkan imajinasi anak.(Muhammad Said ursy, 2011: 117)

Pelaksanaan metode bercerita dapat dilakukan jika tidak ada alat peraga yang konkrit. Dalam kegiatan bercerita tersebut yang berperan adalah guru dengan cara bercerita melalui ekspresi yang tepat. Mamhmud Yunus (1983: 19) dalam menggunakan metode ini ada beberapa hal yang harus diperhatkan di antaranya adalah, sebagai berikut:

1. Guru harus menunjukkan mimik muka, gerakan-gerakan tangan dan kaki serta suara sebagai pencerminan dan penghayatan secara sungguh-sungguh terhadap isi dan alur cerita.

2. Dalam bercerita harus menggunakan bahasa yang jelas, komunikasi dan mudah di mengerti oleh anak

3. Sebelum bercerita aturlah posisi duduk siswa dan guru

4. Selama bercerita hindari teguran pada anak.

Teknik bercerita tanpa menggunakan alat peraga dan maupun tanpa bantuan media gambar, yang dilaksanakan oleh guru Pendidikan Agama Islam di SD N 07 Sumanik dalam penanaman nilai-nilai karakter, sebagai bentuk pemilihan teknik bercerita yang ada dan sudah sesuai dengan prosedur atau langkah-langkah maupun kaidah-kaidah yang harus diperhatikan ketika memilih teknik bercerita tanpa alat peraga dalam pelaksanaan metode bercerita dalam penanaman nilai-nilai karakter kepada siswa, meskipun masih ada yang belum sesuai dengan prosedur.

\section{Menyuruh siswa menceritakan kembali cerita yang telah disampaikan}

Berdasarkan hasil observasi dan wawancara dengan responden dalam 
penanaman nilai-nilai karakter pada Pendidikan Agama Islam melalui metode bercerita di SD N 07 Sumanik, diketahui bahwa pada kegiatan ini guru Pendidikan Agama Islam melakukan dengan memberikan pertanyaan kepada siswa untuk membantu siswa dalam menyampaikan cerita atau menyuruh siswa menceritakan kembali cerita yang telah disampaikan oleh guru.

Kegiatan sebagai salah satu bentuk evaluasi dalam bercerita, untuk mengetahui siswa memahami atau tidak dan mengerti apa yang telah diceritakan oleh guru, di samping itu juga untuk membantu kreatifitas siswa dalam menyampaikan cerita itu kembali, yang siswa menyampaikan dengan bahasa mereka sendiri, sehingga kreatifitas mereka bisa terlatih terutama dalam berbahasa.

Menceritakan kembali cerita yang telah disampaikan oleh pencerita (guru) juga bisa sebagai bentuk dalam kegiatan evaluasi terhadap cerita yang disampaikan, disamping juga untuk melatih imajinasi berfikir siswa serta kemampuan bahasa siswa, tidak hanya kognitif siswa saja, akan tetapi melalui aktifitas menceritakan kembali cerita yang didengar oleh siswa juga melatih keterampilan siswa. jadi, dalam pelaksanaan metode bercerita pada kegiatan atau aktifitas siswa menceritakan kembali cerita yang disampaikan oleh pencerita (guru) lebih baiknya menunjuk atau menentukan siswa yang akan menceritakan kembali secara bergantian, dengan ini keterampilan, kreatifitas siswa dalam mengembangkan imajinasi serta bahasa dapat lebih leluasa dan teramati lebih baik.

Dalam penelitian ini, penelitian relevan yang penulis temukan yaitu penelitian tentang Pembentukan Karakter Melalui Pendidikan Agama Islam oleh Nur Ainiyah (2013). Dalam penelitiannya "karakter seseorang muncul darisebuah kebiasaan yang berulang-ulang dalam waktu yang lama sertaadanya teladan dari lingkungan sekitar. Pembiasaan itu dapatdilakukan salah satunya dari kebiasaan prilaku keberagamaan anakdengan dukungan lingkungan sekolah, masyarakat dan keluarga. Sedangkan upaya yang dapat dilakukan sekolah dalam memaksimalkanpembelajaran PAI di sekolah di antaranya: (1) dibutuhkanguru yang profesional dalam arti mempuni dalam keilmuannya,berakhlak dan mampu menjadi teladan bagi siswanya, (2) pembelajarantidak hanya dilakukan di dalam kelas tetapi ditambah dengankegiatan-kegiatan ekstrakurikuler keagamaan yang dilaksanakandengan serius sebagai bagian pembelajaran, (3) mewajibkan siswamelaksanakan ibadah-ibadah tertentu di sekolah dengan bimbinganguru (misalnya rutin melaksanakan salat zduhur berjamaah), (4)menyediakan tempat ibadah yang layak bagi kegiatan keagamaan, (5)membiasakan akhlak yang baik di lingkungan sekolah dan dilakukanoleh seluruh komunitas sekolah (misal program salam, sapa, dansenyum), (6) hendaknya semua guru dapat mengimplementasikanpendidikan agama dalam keseluruhan materi yang diajarkan sebagaiwujud pendidikan karakter secara menyeluruh. Jika beberapa haltersebut dapat 
terlaksana niscaya tujuan pendidikan nasional dalammenciptakan anak didik yang beriman dan bertakwa kepada tuhanyang maha esa, berakhlak mulia, sehat, berilmu, cakap, kreatif,mandiri, dan menjadi warga negara yang demokratis serta bertanggungjawab dapat tercapai".

\section{PENUTUP}

\section{Kesimpulan}

Dari hasil penelitian yang telah dilakukan di SD N 07 Sumanik Nagari Sumanik Kecamatan Salimpaung Kabupaten Tanah Datar terhadap penanaman nilai-nilai karakter dalam Pendidikan Agama Islam melalui metode bercerita, dapat disimpulkan beberapa hal, yaitu:

1. Pelaksanaan metode bercerita dalam penanaman nilai-nilai karakter pada Pendidikan Agama Islam di SD N 07 Sumanik Nagari Sumanik Kecamatan Salimpaung Kabupaten Tanah Datar, guru PAI bercerita dengan teknik bercerita tanpa menggunakan media gambar yang mengandalkan gaya bahasa, intonasi serta mimik wajah dalam menyampaikan cerita kepada siswa.

2. Cerita yang disampaikan pada pembelajaran Pendidikan Agama Islam dalam penanaman nilai-nilai karakter kepada siswa berkaitan dengan materi yang akan atau hendak dipelajari, sehingga membantu dan memudahkan pemahaman siswa terhadap materi pelajaran. Nilai-nilai karakter yang ditanamkan melalui cerita yang disampaikan yaitu: (1) nilai karakter religious, (2) jujur, 3) Toleransi, (4) kerja keras, (5) rasa ingin tahu, (6) semangat kebangsaan, (7) menghargai prestasi, (8) bersahabat/komunikatif, (9) cinta damai, (10) peduli sosial, (11) tanggung jawab.

\section{Saran}

Berdasarkan kesimpulan di atas, dapat disampaikan beberapa saran sebagai berikut:

1. Guru diharapkan pada proses pembelajaran PAI dalam melaksanakan metode bercerita, hendaknya menyelingi dengan teknik bercerita menggunakan bantuan alat peraga dan menggunakan media gambar, agar proses pembelajaran lebih menarik perhatian siswa dan membantu dalam menyampaikan materi serta memudahkan siswa memahami materi.

2. Guru dalam menyajikan cerita hendaknya jangan terlalu focus pada jenis cerita Islami saja atau kisah para Nabi dan Sahabat, difariasikan dengan jenis cerita lain, seperti: kisah dari tokohtokoh perjuangan nasional, seperti: Buya Hamka, Soedirman, Imam Bonjol dan lain-lain, atau jenis cerita tentang pemimpin, seperti: Soekarno, Soeharto, B.J Habibie dan lain-lain. Sehingga nilainilai karakter yang ditanamkan kepada siswa makin luas dan banyak lagi. 


\section{KEPUSTAKAAN ACUAN}

Abu Ahmadi dan Nur Uhbiyati,2001Ilmu

Pendidikan, Jakarta: PT. Rineka Cipta.

Abdul Aziz Abdul Majid,2002.Mendidik dengan

Cerita, Bandung: Remaja Rosda Karya.

Abudin Nata, 2014.Sosiologi Pendidikan

Islam, Jakarta; PT. Raja Grafindo Persada.

Ahmad, D. Marimba, 1989.Pengantar Filsafat

Pendidikan Islam, Bandung: PT. Al-

Ma'arif.

Ahmad Tafsir, 1992.Ilmu Pendidikan dalam Perspektif Islam, Bandung: Remaja Rosdakarya.

Arif Rohman,2009.Politik Idiologi Pendidikan.

Yogyakarta: Laksbang Mediatama.

Bachri, S Bachtiar, 2005.Pengembangan

Kegiatan Bercerita, Teknik dan Prosedurnya, Jakarta: Depdikbud.

Burhan Bungin, 2001.Metodologi Penelitian

Kualitatif. Aktualisasi Metodologis Kearah

Ragam Kontemporer, Jakarta: Raja

Grafindo Persada.

Chatib Toha, 2000.Kapita Selekta Pendidikan Islam, Yogyakarta: Pustaka Pelajar.

Daniel H. Pink,2010.Misteri Otak Kanan Manusia, Jogjakarta: Think.

Direktorat Pembinaan Pendidikan Anak Usia Dini, Nonformal dan Informal, Kementerian Pendidikan Nasional, Pedoman Pendidikan Karakter Pada Pendidikan Anak Usia Dini, 2012.
Depdiknas, Undang-undang Nomor 20 Tahun 2003 tentang Sistem Pendidikan Nasional, Jakarta: Depdiknas 2003

Permainan Membaca dan Menulis Taman Kanak-Kanak, Jakarta: Departemen Pendidikan Nasional, 2000.

Departemen Pendidikan Nasional, Kamus Bahasa Indonesia, Jakarta: Balai Pustaka, 2007.

Echols, John M. dan Hassan Shadily,1987. Kamus Inggris Indonesia. Jakarta: Gramedia. Cet XV.

Eddy Supriadi,2003.Strategi Belajar Mengajar, Jakarta: LPGTK Tadika Puri.

Enny Zubaidah, Pemilihan Nilai Karakter Dalam Cerita Anak dan Teknik Penceritaannya, Jurnal Pendidikan Anak, Volume II, Edisi 2, Desember 2013.

F.J. McDonal,1959 Educational Psychology, California: Wadsworty.

Harold H. Titus, 1979.Living Issues in Philosophy, New York: Van Nostrand Company.

Hj. Nur Uhbiyati, 1987. Ilmu Pendidikan Islam, Bandung: CV. Pustaka Setia.

Kementerian Pendidikan Nasional, Pengembangan Pendidikan Budaya dan Karakter Bangsa-Pedoman Sekolah, Jakarta: Badan Penelitian dan Pengembangan, 2010.

Kevin Ryan \& Karen E. Bohlin, Building Character: How Our Schools Can Teach Respect and Responsibility. New York, Toronto, London, Sydney, Aucland: Bantam Books, 1999. 
Lexy J. Moleong, M. A., Metodologi Penelitian Kualitatif. Bandung: PT. Remaja Rosdakarya, 2004.

Mathew B. Milles \&A. Michel Hubermen,1992. Analisis Data Kualitatif, terj. Tjejep Rohendi Rohidi, Jakarta: UI Press.

Moeslichatoen R,2004Metode Pengajaran di Taman Kanak-Kanak, Jakarta: Asdi Mahasatya.

Nana S Syaodih, Metode Penelitian Pendidikan. Bandung: PT Remaja Rosdakarya, 2010.

Nur Ainiyah, Pembentukan Karakter Melalui Pendidkkan Agama Islam, Jurnal Al-Ulum Volume 13 No. 1 Juni 2013 Hal-25-38. (Diakses Internet Sabtu, 16 Januari 2016).

Nurbianii Dhieni, dkk. Metode Pengembangan Bahasa. Jakarta: Universitas Terbuka, 2008.

Otib Satibi Hidayat, 2000. Metode Pengembangan Moral Dan Nilai-Nilai Agama. Jakarta: Universitas Terbuka.

Prayitono dan Balferik Manullang, 2010. Pendidikan Karakter Dalam Pembangunan Bangsa, Medan; Pasca Sarjana Universitas Negeri Medan.

S. Nasution, 2006.Metodologi Research (Penelitian Ilmiyah), Jakarta: Bumi Aksara.

Sugiyono, 2011.Metodologi Penelitian Pendidikan, Bandung: Alfabeta.

Suharsimi Arikunto, 1993.Organisasi dan Administrasi Pendidikan Teknologi dan Kujuruan. Jakarta: PT Raja Grafindo.
Vivit Risnawati, Optimalisasi Pendidikan Karakter Anak Usia Dini Melalui Sentra Main Peran di Taman Kanak-Kanak Padang,Jurnal Pesona Paud Vol. 1, No. 1. Verna Hildebrand, 1971. Introduction to Early Children Education. New York: Mc. Millan Publishing Co-Inc.

Winda Gunarti, dkk, 2010.Metode Pengembangan Perilaku dan Kemampuan Dasar Anak Usia Dini, Jakarta: Universitas Terbuka.

Werkanis dan Marlius Hamdi, 2005.Strategi Mengajar, Riau: Sutra Benta Perkasa.

Zakiah Darajat, 2004.Metode Khusus Pengajaran Agama Islam, Jakarta: Bumi Aksara.

....., Ilmu Pendidikan Islam, (Jakarta: Bumi Aksara, 1992, cet ke-2.

Zubaedi. 2012. Desain Pendidikan Karakter. Jakarta: Kencana Prenada Media Group. Zuhairini, Filsafat Pendidikan Islam, Jakarta: Bina Aksara, 1995.

http://file.upi.edu/Direktori/FPBS/ J U R ._ P E N D . _ B A H A S A _ ARAB/195604201983011-SOFYAN_ SAURI/makalah2/NILAI.pdf. (diakses pada Minggu 17 Januari 2016).

http://disdik.bekasikab.go.id/beritapengertian-dan-tujuan-pendidikan-disekolah-dasar.ht 